\title{
The Effect of Macro Economic Variables on Stock Return of Companies That Listed in Stock Exchange: Empirical Evidence from Indonesia
}

\author{
Aminullah Assagaf ${ }^{1}$, Etty Murwaningsari ${ }^{1}$, Juniati Gunawan $^{1} \&$ Sekar Mayangsari $^{1}$ \\ ${ }^{1}$ Faculty of Economics and Business, Trisakti University, Indonesia \\ Correspondent: Aminullah Assagaf, Sudirman Park Apartment, B/03/AD, KH Mas Mansyur Kav. 35 Jakarta \\ Indonesia. E-mail: assagaf29@yahoo.com
}

Received: May 1, 2019

Accepted: June 10, 2019

Online Published: July 9, 2019

doi:10.5539/ijbm.v14n8p108

URL: https://doi.org/10.5539/ijbm.v14n8p108

\begin{abstract}
This study aims to analysis the effect of macroeconomic variables on the overall return of company shares which is a proxy with changes in the composite stock price index.

This study uses secondary data in a period of 20 months from November 2016 to June 2018. While the analysis technique uses multiple linear regression

This study found that macroeconomic variables consisting of inflation rates, interest rates, money supply, and foreign exchange rates, stock returns have a significant effect on companies on the Indonesia Stock Exchange.
\end{abstract}

Keyword: macro economy, agency theory, financial management

\section{Introduction}

Most research shows that inflation has a significant impact on stock returns. Whether the impact is positive or negative, however, is a matter of much debate. Chen et al (2005) concluded that inflation cannot predict stock returns. According to Tripathi and Kumar (2014), the relationship between inflation and stock returns in BRICS is contradictory, with Russia showing a significant negative relationship, while India and China show a significant positive relationship.

Priyono, (2016, 2018, 2019), Priyono, Briyan Cadalora Putra Cisa Cadalora Putri, (2019), states that there are two traditional peak annual inflation in Indonesia. The December-January period always brings higher prices due to Christmas and New Year celebrations, while traditional flooding in January (in the middle of the rainy season) results in disruption of distribution channels in several regions and cities, resulting in higher logistical costs. The second peak of inflation occurred in the July-August period. Inflationary pressure in these two months came as a result of holidays, Muslim holy fasting month, Eid al-Fitr and the beginning of the new school year. Significant improvements can be detected in expenditures on food and other consumables (such as clothing, bags and shoes), along with retailers who adjust prices upwards.

From the research results of Priyono, Briyan Cadalora Putra Cisa Cadalora Putri , $(2016,2018$, 2019), it was stated that the social implications of policy makers could apply empirical evidence in the time series as a theoretical foundation while establishing fiscal, monetary or exchange rate policies to stabilize output and employment opportunities using interest rates, the amount money supply, and exchange rates in other cities.

Abedallat and Shabib (2012) studied the impact of macroeconomic indicators such as changes in investment and gross domestic product (GDP) as independent variables and the movement of the Amman Stock Exchange index as the dependent variable for the 1990-2009 data period. They found the relationship between the two macroeconomic indicators (investment and GDP) and the Amman Stock Exchange index, and also between each separately and the stock index, which means that price movements on the Amman Stock Exchange are influenced by the movements of these two variables, and there are influences both of these variables towards the Amman Stock Exchange index movement. Furthermore, they found the impact of investment changes was greater than the impact of changes in GDP on the Amman Stock Exchange index.

Gunsel and Cukur (2007) analysis the effect of macroeconomic factors on London stock returns for the period between 1980 and 1993. They developed seven predetermined macroeconomic variables. The term structure of 
interest rates, risk premiums, exchange rates, money supply, and unanticipated inflation, sectoral dividend yields and sectoral unexpected production are used as independent variables and returns on London shares as the dependent variable. The results show that macroeconomic factors have a significant influence on the UK stock market but; each factor can affect different industries in different ways. That is, macroeconomic factors can affect one industry positively, but negatively affect other industries

Interest rates are defined as the price of money. This is the proportion of loan funds demanded by investors for the use of these funds. Many governments use interest rates as a monetary policy tool to control other macroeconomic variables such as investment, inflation and unemployment. Alam and Uddin (2009) found that interest rates have a significant negative relationship with stock prices for 15 developed and developing countries using data from 1988 to March 2003. According to Humpe and Macmillan (2007), stock prices are negatively correlated with the long term interest rates in the US and Japan.

The stock market is very important in the economic development of an economy given its role as an intermediary between borrowers and lenders. The stock market is very important in Indonesia mobilizing long-term capital to listed companies by collecting funds from different investors to enable them to expand their business, and offering investors alternative investment paths to enter their surplus funds. In addition, the level of economic stock market development is the main factor in determining overall financial development and sustainability (Ashaolu \& Ogunmuyiwa, 2010). A well-functioning stock market contributes to economic development through more efficient allocation of resources and increasing savings (Junkin, 2012).

Previous studies concluded that changes in stock prices are related to macroeconomic factors. According to Liu and Shrestha (2008), a country's macroeconomic activity has an effect on stock market returns. Muradoglu et al (2000) show that changes in stock prices are related to macroeconomic behavior in developed countries. The Arbitrage Price Theory (APT) championed by Stephen Ross (1976) also provides a theoretical framework for the relationship between stock prices and macroeconomic fundamentals by modeling them into linear functions in which sensitivity to changes in each factor is represented by beta-specific factors. Stock prices, therefore stock returns are generally believed to be determined by some fundamental macroeconomic variables such as interest rates, inflation, exchange rates, and Gross Domestic Product (Kirui, Wawire and Ono, 2014).

From some of the studies above the authors are interested in analyzing themed studies:

The Effect Of Macro Economic Variables On Stock Return Of Companies That Listed In Stock Exchange : Empirical Evidence From Indonesia.

Furthermore, this study can be formulated as the following hypothesis:

1. It is assumed that the inflation rate has an effect on Stock Return

2. It is assumed that the interest rate has an effect on Stock Return

3. Suspected money supply has an effect on Stock Return

4. Exchange rate is expected to have an effect on Stock Return

\section{Research Methods}

\subsection{Data and Sample}

The study used macroeconomic data reported online by related institutions such as Indonesian banks, Indonesia Stock Exchange, Central Bureau of Statistics, and others. The macroeconomic data used consisted of the inflation rate, the average interest rate prevailing in the bank at the time of observation, the amount of money in circulation, the development of the foreign exchange or the US dollar against the value of the IDR, and the development of the overall stock return of listed companies in the Exchange Effect Indonesia.

This study uses monthly time series data from November 2016 to June 2018 or 20 months of observation. The reason for using this timeframe is mainly to explain the current phenomenon which can be explained in the previous few months, since using long-term data several years earlier is less realistic than the short monthly period as conducted in this study.

\subsection{Variable Measurement}

Variable used in this study consisted of the dependent variable of the overall return rate of firms in Indonesia Stock Exchange, and four independent variables consisting of inflation rate, interest rate, amount of money in circulation, and US dollar exchange rate against rupiah value, as stated below .

(a) The dependent variable of the company's stock return rate $\left(\mathrm{YR}_{\mathrm{i}}\right)_{-}$as a whole company listed on the Indonesia Stock Exchange, in proxy by using the composite stock price index or JCI between the time that is the growth rate 
of the index from time to time representing the company's listed on the Indonesia Stock Exchange. Measurement of the dependent variable of overall company return rate listed on the Indonesia Stock Exichange is formulated as follows.

$$
\text { YRi }=\frac{\operatorname{IHSG}(\mathrm{t})-\operatorname{IHSG}(\mathrm{t}-1)}{\text { IHSG }(\mathrm{t}-1)}
$$

(b) The independent variable of inflation rate or $\mathrm{X}_{1} \mathrm{INF}_{\mathrm{i}}$ is the development of the price of goods in general which is calculated based on the price development of certain goods.

(c) The independent variable interest rate or $\mathrm{X}_{2} \mathrm{INT}_{\mathrm{i}_{-}}$is the development of interest rates prevailing in government banks and private banks. Interest rates affect the economic development of society because with high interest rates will reduce the development of investment and impact on job opportunities or trigger the growth of the number of unemployed. The limited capability of the company's investment in Indonesia Stock Exchange will affect the stock price of the company in general, so that the composite stock price index will decrease.

(d) Variable independent money supply or $\mathrm{X}_{3} \mathrm{MNS}_{\mathrm{i}}$ is the amount of money circulating in a society controlled by an Authority in the context of stabilizing the national economy, because the excess or shortage of money in circulation will have an impact on the economy of the people and companies listed on the Indonesia Stock Exchange.

(e) The independent variable US dollar exchange rate against the IDR or $\mathrm{X}_{4} \mathrm{EXC}_{\mathrm{i}}$ is the level of development of foreign exchange rates over time. Changes in the US dollar exchange rate against the IDR will affect the business and social economic development in general. With an increasing exchange rate impacts the company's financial performance on the Indonesia Stock Exchange, thus affecting stock prices in general and causing the composite stock price index to be depressed.

Measurement of independent variable inflation rate or $\mathrm{X}_{1} \mathrm{INF}_{\mathrm{ii}}$, interest rate or $\mathrm{X}_{2} \mathrm{INT}_{\mathrm{i}}$, money supply or $\mathrm{X}_{3} \mathrm{MNS}_{\mathrm{i}}$, and the US dollar exchange rate against the IDR or $\mathrm{X}_{4} \mathrm{EXC}_{\mathrm{i}}$ was measured by using the data as reported and published online by Bank Indonesia through https://www.bi.go.id/

\subsection{Model Analysis}

$$
\mathrm{YR}_{\mathrm{i}}=\beta_{0}+\beta_{1} \mathrm{X}_{1} \mathrm{INF}_{\mathrm{i}}+\beta_{2} \mathrm{X}_{2} \mathrm{INT}_{\mathrm{i}}+\beta_{3} \mathrm{X}_{3} \mathrm{MNS}_{\mathrm{i}}+\beta_{4} \mathrm{X}_{4} \mathrm{EXC}_{\mathrm{i}}+\mathrm{e}_{\mathrm{i}}
$$

Where: $Y R i=$ stock return, $X_{1} I N F_{i}=$ inflation rate, $X_{2} I N T_{i}=$ interest rate, $X_{3} M_{N} S_{i}=$ money supply, $X_{4} E X C_{i}=$ exchange rate, $\beta_{0}=$ Constant, $\beta_{1} \ldots . . \beta_{4}=$ Coefficient regression, $\mathrm{e}_{\mathrm{i}}=$ error.

\subsection{Analytical Framework}

The empirical changes that occur on the stock return of the company in general in Indonesia Stock Exchange is influenced by macroeconomic variable, so the changes that occur macroeconomic conditions will affect the stock price of the company depends on how much the level of sensitivity influence of these variables on stock returns of each company. The correlation between the macroeconomic variables and the overall stock returns of the company in the Indonesia Stock Exchange is illustrated below.

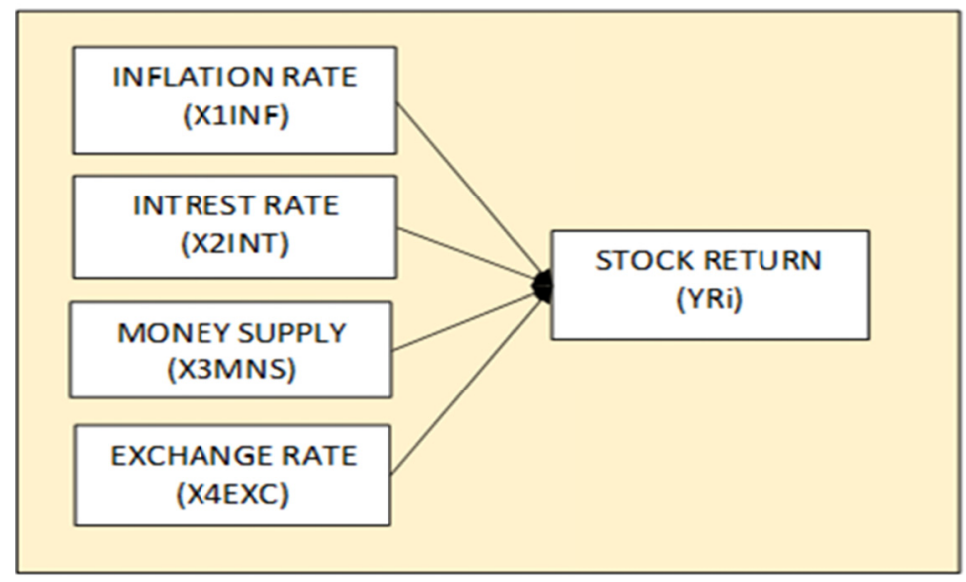

Figure 1. Figure framework concepts 
Overall companies listed on the Indonesia Stock Exchange with a joint stock price index that changes according to the level of changes in macroeconomic conditions. An important variable in macroeconomics is the rate of inflation that affects the price of goods in general in society. The interest rate as a macroeconomic variable also plays an important role in influencing the growth of company performance, because the interest rate has a direct impact on investment and this means that the company on the Stock Exchange will experience obstacles in investment if the interest rate increases. Therefore, changes in the benchmark interest rate decided by the central bank will have an impact on the company's overall stock price which is replicated by changes in the joint stock price index. Macroeconomic variables from the money supply have an impact on the national economic situation, because the money supply that exceeds national economic needs will have an impact on the performance of companies on the Indonesia Stock Exchange, because there is an balance between the amount of money in circulation and the goods available. causing scarcity of products and will affect the development of the company on the Stock Exchange due to uncertainty. Operational decisions tend to be short-term, because long-term sale and purchase contracts tend to harm the seller both from the sale of the final product or the supplier of raw materials, thus affecting the stock price on the Indonesia Stock Exchange.

The exchange rate of the dollar against the unstable value of the IDR tends to exacerbate the return of company shares as a whole, because such conditions will be used by speculators to reap profits. Therefore, the dollar exchange rate variable against the value of the IDR is one of the macroeconomic variables that affects the stability of the return of shares on the Indonesia Stock Exchange, because investors who transact are not only from local investors but also foreign investors who have strong capital potential.

\section{Result and Discuss}

\subsection{Descriptive Statistics}

The structure of the research data such as Table 1 Descriptive Statistics shows the variation between each variable, namely:

(a) The dependent variable from the market return or YRi,_Stock Return varies from a minimum value of 5.15 to a maximum value of 6.61 with an average value of 5.86 and a level of deviation or standard deviation of 0.398 .

(b) The independent variable of the inflation rate or $\mathrm{X} 1$ _ inflation rate varies from a minimum value of 3.02 to a maximum value of 4.37 with an average value of 3.59 and a level of deviation or standard deviation of 0.385 .

(c) The independent variable interest rate or $\mathrm{X} 2$ _ Interest rate varies from a minimum value of 8.40 to a maximum value of 11.21 with an average value of 10.37 and a level of deviation or standard deviation of 0.756 .

(d) Independent variable money supply or X3_Money Supply varies from a minimum value of 4.87 to a maximum of 5.46 with an average value of 5.21 and a deviation rate or standard deviation of 0.188 .

(e) Independent variables of currency exchange rates vary from a minimum value of 13.38 to a maximum of 14.95 with an average value of 13.66 and a level of deviation or standard deviation of 0.405 .

Table 1. Descriptive statistics

\begin{tabular}{llrrrc}
\hline & N & Minimum & Maximum & \multicolumn{1}{c}{ Mean } & Std. Deviation \\
\hline YRi & 20 & 5.15 & 6.61 & 5.8560 & .39803 \\
X1_InrestRate & 20 & 3.02 & 4.37 & 3.5950 & .38567 \\
X2_InflatioRate & 20 & 8.40 & 11.21 & 10.3685 & .75659 \\
X3_MoneySupply & 20 & 4.87 & 5.46 & 5.2118 & .18808 \\
X4_ExchaneRate & 20 & 13.38 & 14.95 & 13.6619 & .40511 \\
Valid N (listwise) & 20 & & & & \\
\hline
\end{tabular}

Where: Yri=inflation rate, $\mathrm{X} 1 \_$InflationRate $=$inflation rate, $\mathrm{X} 2$ _Intrest Rate=I ntrest rate,

X3_MoneySupply= money supply, X4_ExchangeRate $=$ exchange rate.

\subsection{Correlations}

The calculation results of the correlation coefficient between variables as Table 2 Correlation: 
(a) the independent variable inflation rate (X1_ Inflation Rate) correlates with the dependent variable YRi_Stock Return of 0.197 , which means that the level of closeness of the relationship between these two variables is relatively small or less than 0.50 .

(b) the interest rate independent variable (X2_Interest Rate) correlates with the dependent variable YRi_Stock Return of 0.866, which means that the level of closeness of the relationship between these two variables is relatively strong or greater than 0.50 .

(c) the independent variable of the money supply (Supply X3_Money) correlates with the dependent variable YRi_Stock Return of 0.827 , which means that the relationship between the two variables is relatively strong or greater than 0.50 .

(d) the independent variable of the exchange rate (X4_Exchange Rate) correlates with the dependent variable YRi_Stock Return of 0.217 , which means the level of closeness of the relationship between these two variables is relatively small or less than 0.50 .

Table 2. Correlations

\begin{tabular}{|c|c|c|c|c|c|}
\hline & $\begin{array}{l}\text { YRi_Stock } \\
\text { Return }\end{array}$ & $\begin{array}{c}\text { X1_Inflation } \\
\text { Rate }\end{array}$ & X2_Intrest & $\begin{array}{c}\text { X3_Money } \\
\text { Supply }\end{array}$ & $\begin{array}{c}\text { X4_Exchange } \\
\text { Rate }\end{array}$ \\
\hline YRi_StockReturn & 1 & & & & \\
\hline X1_InflationRate & -.197 & 1 & & & \\
\hline X2_IntrestRate & $-.866^{\star *}$ & .374 & 1 & & \\
\hline X3_MoneySupply & $.827^{\star *}$ & -.348 & $-.613^{\star \star}$ & 1 & \\
\hline X4_ExchangeRate & .217 & $-.474^{*}$ & -.271 & $.581^{* *}$ & 1 \\
\hline
\end{tabular}

\subsection{Classic Assumption Test}

\section{Normality}

Based on the calculation of SPSS, the value of Asymp Sig (2-tailed) is 0, 153>0,05 or 5\%, so it is stated that the data used in this regression calculation is normal distribution.

\section{Multicollinearity}

The result of multicollinearity test as in Table 3 shows collinearity statistics on each independent variable obtained tolerance value $>0,01$, and variance inflation factor or $\mathrm{VIF}<10$, so it is stated that in this regression there is no indication of multicollinearity.

\section{Autocorrelation}

By using the Durbin-Watson test as the result of calculation on Table 3 obtained the value of DW statistics $=2,645$ larger $\mathrm{dU}=1,8282$ and smaller than $4-\mathrm{dL}=3,1057(\alpha=5 \%, \mathrm{n}=20$, and $\mathrm{k}=4)$, so it is stated that in this regression there are no symptoms of autocorrelation.

\section{Heteroskedastic}

Using Glejser method as the result of SPSS calculation obtained Sig value. each independent variable greater than 0.05 so it is stated that in the regression there are no symptoms of heteroskedastic. From the calculation of Glejser approach, the significance level of the relationship between independent variable and residual is greater than 0.05 : Inflation rate or X1_Inflation Rate $=0,413$, Interest rate or X2_Interest Rate $=0,779$, money supply or X3_Money Supply $=0,054$, and foreign exchange rate or X4_Exchange Rate $=0.065$.

\section{Hypothesis Testing}

Hypothesis test with the result of calculation as Table 3 shows Sig value. which is less than 0.01 or $1 \%$, so it can be stated: 
(a) H1 hypothesis proven or result of calculation in accordance with hypothesis proposed in this research, that inflation rate have a significant effect to stock return of whole company in Indonesia Stock Exchange projected with index of joint price of share, with indigo Sig. $=0.032$.

(b) $\mathrm{H} 2$ hypothesis proven or calculation results in accordance with the hypothesis proposed in this study, the interest rate has a significant effect on the overall stock return of the company on the Indonesia Stock Exchange is projected with the price index of joint stocks, with indigo Sig. $=0,000$.

(c) H3 hypothesis proved or calculated in accordance with the hypothesis proposed in this study, the money supply has a significant effect on the overall stock return of the company on the Indonesia Stock Exchange is projected with a composite price index, with indigo Sig. $=0,000$.

(d) H4 hypothesis proved or the result of calculation in accordance with the hypothesis proposed in this study, namely the value of foreign exchange rates significantly affect the stock return of the entire company in the Indonesia Stock Exchange is projected with the index of joint stock prices, with indigo Sig. $=0,000$.

Table 3. The effect of macroeconomic variable on stock return

$\mathrm{YR}_{\mathrm{i}}=\beta_{0}+\beta_{1} \mathrm{X}_{1} \mathrm{INF}_{\mathrm{i}}+\beta_{2} \mathrm{X}_{2} \mathrm{INT}_{\mathrm{i}}+\beta_{3} \mathrm{X}_{3} \mathrm{MNS}_{\mathrm{i}}+\beta_{4} \mathrm{X}_{4} \mathrm{EXC}_{\mathrm{i}}+\mathrm{e}_{\mathrm{i}}$

\begin{tabular}{|c|c|c|c|c|c|}
\hline \multirow[b]{2}{*}{ Variables } & \multirow[b]{2}{*}{ Predict. } & \multirow[b]{2}{*}{ Coefficient } & \multirow[b]{2}{*}{ Significant } & \multicolumn{2}{|c|}{ Collinearity Statistics } \\
\hline & & & & Tolerance & VIF \\
\hline (Constant) & & 4.693 & $4.958 * * *$ & & \\
\hline X1_InflationRate & + & 0.127 & $2.370 * *$ & .705 & 1.418 \\
\hline X2_IntrestRate & - & -0.300 & $-9.810 * * *$ & .563 & 1.775 \\
\hline X3_MoneySupply & + & 1.436 & $10.262 * * *$ & .435 & 2.298 \\
\hline X4_ExchangeRate & - & -0.269 & $-4.638^{* * *}$ & .548 & 1.825 \\
\hline Adjusted $\mathrm{R}^{2}$ & 0.96 & & & & \\
\hline F-Statistics & 127.63 & & & & \\
\hline Sig. & 0.000 & & & & \\
\hline Durbin-Watson & 2.645 & & & & \\
\hline Obs & 20 & & & & \\
\hline
\end{tabular}

From the calculation results as Table 3 and based on the analysis model used, the regression equation is presented below.

$$
\text { YRi }=4.693+0.127 \mathrm{X}_{1} \mathrm{INF}_{\mathrm{i}}-0.300 \mathrm{X}_{2} \mathrm{INT}_{\mathrm{i}}+1.436 \mathrm{X}_{3} \mathrm{MNS}_{\mathrm{i}}-0.269 \mathrm{X}_{4} \mathrm{EXC}_{\mathrm{i}}
$$

The coefficient of each of these variables can be explained that: (a) an increase of inflation (X1INF) of $1 \%$ will result in an increase in return market by $0.127 \%$, (b) an increase in interest rate (X2INT) of $1 \%$ will have a decrease in market return of 0.300 (d) the increase of the money supply (X3MNS) by $1 \%$ will affect the $1.436 \%$ market return increase, and (d) the increase of the foreign exchange rate (X4EXC) by $1 \%$ will reduce the market return by $0.269 \%$.

\subsection{Coefficient Determinant $\left(R^{2}\right)$}

The result of coefficient determinant $\left(\mathrm{R}^{2}\right)$ as Table 3 shows Adjusted $\mathrm{R}$ Square $=0.96$, which means that this regression is table to explain the phenomenon of $96 \%$ and the remaining $4 \%$ is explained by other factors not taken into account in this research. This means that changes in the stock return of firms on the Stock Exchange can be explained by changes in the independent variables of inflation rate, interest rate, money supply, and foreign exchange rate with a trust rate of $96 \%$.

\section{Statistic $\boldsymbol{F}$}

The simultaneous test of the overall effect of the independent variable on the stock dependent return variable as the result of the calculation on Table 3 shows the Sig value. $=0.000$, so it is stated that the independent variable of inflation rate, interest rate, money supply, and foreign exchange value have a significant effect on stock return of whole company in Indonesia Stock Exchange.

\section{Statistics $t$}

Partial Test performed through statistical tests as in Table 3, which is the independent variable inflation rates, interest rates, and the number of outstanding foreign exchange rates, partially significant effect on the dependent variable total stock return of companies on the Stock Exchange Indonesia. Level of significant relationship 
between variables is smaller than $1 \%$, which means that the hypothesis proposed in this study has been appropriate and supported by the calculation of statistical test $t$.

\section{Discussion}

Based on hypothesis as it is evidenced on the results calculation statistic and pay attention results research earlier as put forward before, then need discussed some $\mathrm{p}$ Relevant principal with the role of macro variables economy in influence stock return whole companies in Indonesia Stock Exchange, namely :

(a) Hypothesis about the effect of macroeconomic variables made from inflation rate, interest rate, amount money outstanding, and currency foreign proven take effect significant to stock return whole companies in the Indonesian Stock Exchange. It is in line with hypothesis above and relevant with results research earlier as it is findings reported at Chen et al (2005), Gunsel \& Cukur (2007), Abedallat \& Shabib (2012).

(b) Research this find that in period short and medium, it turns out level inflation take effect positive against stock return company. It is happen because support of government as it is done moment this to development industry and business world, have an impact to enhancement chance work or push number poverty. Because of unemployment decreased, then as it is Philips theory proves that inflation negative compared with unemployment, because happen enhancement spending consumption home stairs and triggers enhancement inflation, so otherwise when unemployment increased then inflation decrease because community experience difficulty finance and demand decrease although price tend more cheap. The implication, which is inflation is relatively controlled push increase in stock return, so required ethers money policy of the Central Bank and fiscal policies by the government for inflation located position control. The results of this study support the research results of Priyono, (2016, 2018, 2019), Priyono, Briyan Cadalora Putra Cisa Cadalora Putri, (2019)

(c) Implications of interest policy is authority monetary have the role of macroeconomic variable this no impact bad to development of a marked business world with declining stock returns company. Variable interest rate have a negative effect on stock return because with increased interest will push amount investment of industry and business sector, and this means also will improve amount unemployment and pushing growth number poverty. This is where role authority monetary for on wise in use interest rate reference that can influence the bank interest overall.

The results of the study this in line with theory investment, which states that interest rate negatively correlated with investment, or investment is function from interest rate and have a slope or a negative curve, which means that on the interest rate high will cause decline amount investment, otherwise of low interest will push growth investment. If investment experience increase, then the business world increasingly growing, the amount unemployment down, numbers poverty increasingly low, and stock returns company tend experience improvement. this is in line with the opinion: Priyono, Briyan Cadalora Putra Cisa Cadalora Putri, (2019)

(d) amount money outstanding impact positive against stock return, inside period short and long term medium happen growth opportunities business because banking push enhancement funding investment industry and business world, so performance finance company increasingly increase. Enhancement profitability or performance finance industry and business world, and convenience earn funding banking push increase of stock return companies in the Stock Exchange. Implications policy of banking, that is push interest community in optimizing use its revenue, through various policy amenities credit so transaction business increased because community chance use future income for used this moment.

(e) The exchange rate currency foreign have a negative and significant effect against stock return companies in the Securities Exchange are meaningful that point a weakening exchange will cause loss company certain such as : the company that owns debt overseas or debt with value currency foreign, using ingredients default from abroad, imports capital goods, and others. The implication, that investors in the Stock Exchange respond value exchange currency foreign because in general increase value currency foreign, will pressing stock return company on overall characterized with decline index price stock Composite Indonesia Stock Exchange.

\section{Conclusion and Suggestion}

The results of the study this concluded:

(a) In period short and medium, inflation rate take effect positive and significant to stock return of companies on the Indonesia Stock Exchange, which means that increase inflation push increase price stock company. Suggested for monetary policy by central banks and fiscal policies by the government control inflation, because level of inflation the give signal positive for investors in the capital market, so push taking investor decisions within determine its investment portfolio in the Capital Market. 
(b) interest rate have a negative and significant effect to stock return of companies on the Indonesia Stock Exchange, which means that increase interest rate push price stock companies in the Stock Exchange. Suggested for monetary policy to interest rate reference do with take into account the impact to macroeconomic, because that policy very sensitive to investor decisions in the capital market, even in form information about plan increase interest rate reference will trigger movement price shares in the Stock Exchange.

(c) Numbers money outstanding take effect positive and significant to stock return of companies on the Indonesia Stock Exchange, which means that increase amount money outstanding will push increase price stock companies in the Stock Exchange. It is suggested that the central bank control amount money outstanding, due to macroeconomic variables this significant influence against stock return of company on the Stock Exchange, and if this ignored, then impact multiplier will happen on systemic in resonance national level.

(d) Exchange currency foreign have a negative and significant effect to stock return of companies on the Indonesia Stock Exchange, which means that increase value exchange currency foreign will impact to decline price shares in the Stock Exchange. It is suggested that the government control balance sheet transaction walk through share policy such as: push enhancement export, limit import goods consumptive, supervising and controlling debt outside undertaken by the government, state-owned and private cause deficit balance sheet transaction walking .

\subsection{Implication}

Implications for research next is could do research similar with expand period range time for example 5 to 10 years, and use additional macroeconomic variables others that have not used in this study, so could complete this research.

\section{References}

Al-Abedallat, A. Z., \& Al-Shabib, D.K. (2012). Impact of the investment and gross domestic product on the Amman Stock Exchange index. Investment Management and Financial Innovations, 9(3), 130-136

Alam, M. M., \& Uddin, M. G. (2009). Relationship between interest rates and stock prices: empirical evidence from developed and developing countries. International Journal of Business and Management, 4(3), 43-50.

Amin, M. Z., Herawati, T. D. (2012). Pengaruh Tingkat Inflasi, Suku Bunga Sbi, Nilai Kurs Dollar Dan Indeks Dow Jones Terhadap Pergerakan Indeks Harga Saham Gabungan Di Bursa Efek Indonesia (Bei) (Periode 2008-2011). Jurnal Skripsi, 1-17.

Ashaolu, T. O., \& Ogunmuyiwa, M. S. (2011). An Econometric Analysis of the Impact of Macro EconomicVariables on Stock market movement in Nigeria. Journal of Business Management, 3(1), 72-78.

Chen, M. H., Kim, W. G., \& Kim, H. J. (2005). The impact of macroeconomic and non macroeconomic forces on hotel stock returns. Hospitality Management, 24, 243-258.

Gunsel, N., \& Cukur, S. (2007). The effects of macroeconomic factors on the London Stock returns: a sectoral approach. International Research Journal of Finance and Economics, 10, 140-152.

Humpe, A., \& Macmillan, P. (2007). Can Macroeconomic Variables Explain Long Term Stock Market Movements? A Comparison of the US and Japan, Centre for Dynamic Macroeconomic Analysis Working $\begin{array}{llllll}\text { Paper } & \text { Series. } & \text { Retrieved } & \text { 13, February } & & \end{array}$ http://www.st-andrews.ac.uk/economics/CDMA/papers/wp0720.

Jensen, M. C., Meckling, W. H. (1976). Theory of The Firm: Man Age Rial Behavi Or, Agency Costs And Ownership Structure. Journal of Financial Economics, 3(4), 305-360.

Junkin, K. (2012). Macroeconomic determinants of stock market behaviour in South Africa. Rhodes University. Retrieved from http://eprints.ru.ac.za/3658/

Kirui, E., Wawire, H. W., \& Onono, P. O. (2014). Macroeconomic Variables, Volatility and Stock Returns: A Case of Nairobi Securities Exchange, Kenya. International of Economics and Finance, 6(8).

Liu, M., \& Shrestha, K. (2008). Analysis of the long term relationship between Macro-economic variables and the Chinese stock market using heteroscedastic cointegration. Journal of Managerial Finance, 34(11), 744-755.

Muradoglu, G., Metin, K., \& Argac, R. (2001). Is There a Long-Run Relationship between Stock Returns and Monetary Variables: Evidence from an Emerging Market. Applied Financial Economics, 11, 641-649. https://doi.org/10.1080/09603100110094411

Priyono. (2016). Esensi ekonomi makro. Zifatama publisher 
Priyono. (2018). Effect of wage, inflation and exchange rate on the investment policy in Sidoarjo district, Indonesia. East Asia, 35(135), 1-26. https://doi.org/10.1007/s12140-018-9294-5

Priyono. (2019). Some of the Most Influential Investment Issues in Malang, Indonesia, Saudi J Econ Fin, 3(3): 134-150. https:// doi.org/10.21276/sjef.2019.3.3.4

Priyono. Briyan Cadalora Putra Cisa Cadalora Putri, (2019). Tradition of Inflation Affected by Wages, Inflation, and Exchange Rate on the Investment Policies in Indonesia. International Research Journal of Finance and Economics, 172.

Rifai, S. H., Susanti, H., Setyaningrum, A. (2017). Analisis Pengaruh Kurs Rupiah, Laju Inflasi, Jumlah Uang Beredar dan Pertumbuhan Ekspor terhadap Total Pembiayaan Perbankan Syariah dengan Dana Pihak Ketiga sebagai Variabel Moderating. Jurnal Ekonomi dan Perbankan Syariah, 8(1), 13-27.

Ross, S. A. (1976). The Arbitrage Theory of Capital Asset Pricing. Journal of Economic Theory, 13, 341-360.

Swandayani, D. M., Kusumaningtias, R. (2012). Pengaruh Inflasi, Suku Bunga, Nilai Tukar Valas Dan Jumlah Uang Beredar Terhadap Profitabilitas Pada Perbankan Syariah Di Indonesia Periode 2005-2009. Akrual Jurnal Akuntansi, 3(2), 147-166.

Tripathi, V., \& Kumar, A. (2014). Relationship between Inflation and Stock Returns - Evidence from BRICS markets using Panel Co integration Test. International Journal of Accounting and Financial Reporting, $4(2)$.

\section{Copyrights}

Copyright for this article is retained by the author(s), with first publication rights granted to the journal.

This is an open-access article distributed under the terms and conditions of the Creative Commons Attribution license (http://creativecommons.org/licenses/by/4.0/). 